\title{
THE EFFECT OF ADDING SLAG, ACHIEVED FROM WASTEWATER SLUDGE INCINERATION IN FLUIDIZED-BED FURNACE, ON THE QUALITY OF CONCRETE
}

doi: 10.2478/cqpi-2019-0033

Date of submission of the article to the Editor: 17/04/2019

Date of acceptance of the article by the Editor: 12/05/2019

\author{
Alina Pietrzak ${ }^{1}$ - orcid id: 0000-0002-1301-874X \\ ${ }^{1}$ Czestochowa University of Technology / Faculty of Civil Engineering, Poland
}

\begin{abstract}
Due to a constant increase in generating the amount of sewage waste it is necessary to find an alternative method of its use or disposal. One of such methods can be utilization of sewage sludge in construction materials industry, particularly in concrete technology and other materials based on cement. It allows using waste materials as a passive additive (filler) or also as an active additive (replacement of part of bonding material). The article aims at presenting the analysis of the effect of adding slag, achieved from wastewater sludge incineration in sewage treatment plant, on properties and quality of concrete mix and hardened concrete. Using an experimental method, the researcher designed the composition of the control concrete mix, which was then modified by means of slag. For all concrete mixtures determined - air content with the use of pressure method and consistency measured by the use of concrete slump test. For all concrete series the following tests were conducted: compressive strength of concrete after 7, 28 and 56 days of maturing, frost resistance for 100 cycles of freezing and thawing, water absorption. The use of slag, ground once in the disintegrator, causes a decrease of in compressive strength of concrete samples in relation to the control concrete series as well as bigger decrease in compressive strength after frost resistance test.
\end{abstract}

Keywords: concrete, ash, sewage sludge, concrete quality

\section{INTRODUCTION}

Wastewater sludge, produced in sewage treatment plants is considered as waste, whose disposal and management comes as a global problem. According to the Law of $27^{\text {th }}$ April 2001, wastewater sludge needs to be disposed not only for legal reasons but also the esthetic and practical ones. By reason of organic and biogenic compounds content wastewater sludge was used for years in agriculture as a rich source of substances essential for plant growth. However, due to discharge of municipal and industrial waste together wastewater sludge is contaminated by heavy metal compounds, organic substances, pathogenic bacteria and fungi, parasite eggs 
and other dangerous substances. It leads to the situation when biotechnologies used in wastewater sludge treatment are no longer in conformity with the applicable requirements for agriculture or in compost production (Środa, Kijo-Kleczkowska, Otwinowski, 2012; Kosior-Kazberuk, 2011). According to data of Central Statistical Office (GUS), in 2016 in Poland, 568,000 Mg of wastewater sludge were produced in sewage treatment plants. It is connected with a dynamic development of sewage networks and the increase of the amount of municipal wastes delivered to sewage treatment plants (Rutkowska, 2018).

Due to a constant increase in generating the amount of sewage waste it is necessary to find an alternative method of its use or disposal. One of such methods can be utilization of sewage sludge in construction materials industry, particularly in concrete technology and other materials based on cement. The range of mineral additives to concrete has been extended of new types of materials and wastes. On the basis of the subject literature, the following substances are used in the production of concrete mix: volatile ashes, silica fumes, ground blast furnace slag, biofuel ashes (Jura and Ulewicz, 2018; Halbiniak, 2012; Jura and Ulewicz, 2017), and polymers and polymer wastes (Albano, 2009; Mounanga, 2008; Pietrzak and Ulewicz, 2018; Brózda, and Selejdak, 2016; Janecka and Siemiątkowski, 2012). The present article focuses on the quality of concrete, to whose production slag, achieved from wastewater sludge incineration in fluidized-bed furnace in sewage treatment plants, was used.

\section{METHODOLOGY OF THE STUDY}

Contemporary construction puts higher and higher demands on building materials. Buildings erected must be safe, durable, environmentally friendly, at the same time they must meet appropriate economic criteria. All these requirements are met by concrete, provided that it is properly designed and made. The guarantee of proper quality of the produced concrete is connected with using only components that comply with the requirements of the applicable PN-EN 206-1 concrete standard for its intended use and to ensure that the concrete composition complies with the requirements of exposure classes or the type of element being made.

All components should be selected in such a way as to meet the requirements for concrete mix and hardened concrete, including consistency, density, strength and durability, and taking into account the specificity of the technological process and the technology of the work. In order to achieve the above, the main principle should be the use of only the components of a fixed suitability, i.e. those for which the requirements for properties have been described in the relevant reference documents.

The aim of the study was to determine the effect of adding slag, achieved from wastewater sludge incineration, on selected properties and quality of concrete. To produce samples of concrete for the present investigation the following substances were used: Portland cement CEM I 42,5R, washed sand, gravel aggregate of the 2-8 and 8-16 $\mathrm{mm}$ fractions, Master Pozzolith STD plasticizer and slag, achieved from wastewater sludge incineration, ground in disintegrator to dust fraction (Fig.1). The test material (slag) was obtained from a sewage treatment plant located in Bydgoszcz. 

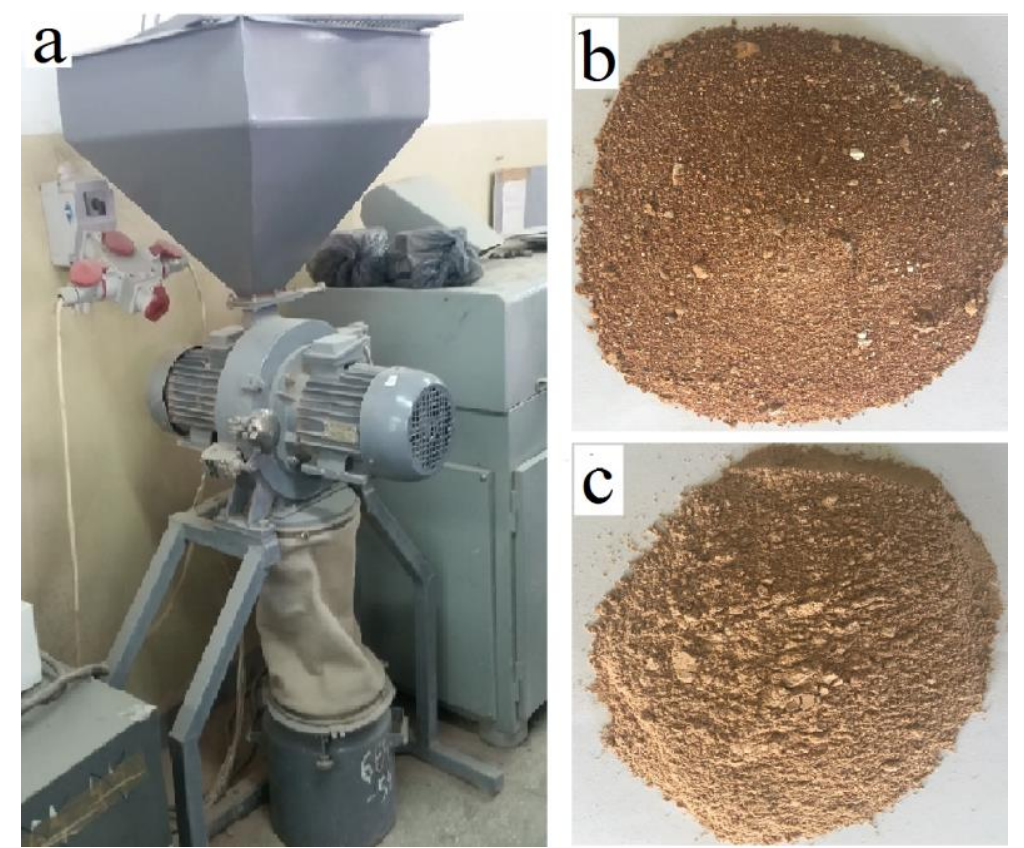

Figure 1. The material used for testing a) disintegrator, b) slag, achieved from wastewater sludge incineration (primary form), c) slag from the fluidized-bed furnace, ground once in the disintegrator (own elaboration)

In order to improve the selected properties of the concrete or to obtain special properties, components called additives are used for concrete. They are added to the concrete mix in an amount exceeding $5 \%$ of the cement mass. The additives should be included in the concrete tightness calculations. Additives used must meet the requirements set in the PN-EN 206 -1: 2014 Concrete standard. According to the aforementioned standard, fly ash is Type II additives and can be included in the composition of the concrete using the coefficient concept " $k$ ". This concept is based on a comparison of the durability of the reference concrete and concrete in which part of the cement was replaced with the type II additive. This allows the inclusion of Type II additives by:

- replacement of the water / cement ratio, water / (cement $+\mathrm{k} x$ additive); - fulfillment of the condition: (cement $+k x$ additive) $\geq$ minimum cement content required due to the specified exposure class.

Rules for the use of the coefficient $k$ for fly ash:

- the maximum amount of flyash included in the value of $k$ should satisfy the condition:

- for CEM I cements - fly ash / cement $\leq 0.33$ (by mass),

- for CEM II / A cements - fly ash / cement $\leq 0.25$ (by mass),

The coefficient $\mathrm{k}=0.4$ for the above condition.

Three series of samples were made. Control concrete sample with the $\mathrm{w} / \mathrm{c}=0.55$ ratio with the addition of plasticizer in the amount of $0.3 \%$ of the cement bulk - (SK) series. In the subsequent attempts the control concrete was modified by:

- series 1 - adding slag from the fluidized-bed furnace, ground once in the disintegrator with a $\mathrm{P} / \mathrm{C}=0.330$ ratio, adjusting the amount of cement and aggregate; 
- series 2 - adding slag from the fluidized-bed furnace, ground once in the disintegrator with a $\mathrm{P} / \mathrm{C}=0.165$ ratio, adjusting the amount of cement and aggregate.

The composition of particular concrete mixes is given in Table 1.

Table 1. The composition of concrete mixes of particular series

\begin{tabular}{|c|c|c|c|c|c|}
\hline \multirow{2}{*}{$\begin{array}{c}\text { Concrete } \\
\text { series }\end{array}$} & \multicolumn{5}{|c|}{ Components (kg/ $\mathbf{m}^{3}$ ) } \\
\cline { 2 - 6 } & Cement & Water & Aggregate & Plasticizer & Slag \\
\hline SK & 313.3 & 173.9 & 1918.2 & 0.94 & - \\
\hline S1 & 279.3 & 173.9 & 1860.8 & 0.84 & 92.17 \\
\hline S2 & 296.6 & 173.9 & 1885.8 & 0.89 & 48.94 \\
\hline
\end{tabular}

Source (own elaboration)

With the experimentally assumed water/cement ratio the concrete mixture was designed in the way to gain appropriate consistency and workability. For the control concrete series the S3 consistency was assumed (slump within 100-150 mm). For all series of concrete samples there were twelve $15 \times 15 \times 15 \mathrm{~cm}$ cubic samples and twelve $10 \times 10 \times 10 \mathrm{~cm}$ samples formed. The experiment of durability of compressive strength was conducted after 7, 28 and 56 days of sample maturing. After 28 days of maturing the following tests were also conducted: frost resistance for 100 cycles of freezing and thawing and water absorption.

The experiment of durability of compressive strength was conducted after 7, 28 and 56 days of sample maturing under laboratory conditions according to Norm PN-EN 206:2014 Concrete - "Specification, performance, production and conformity". The experiment was carried out by mean of Toni Technik type 2030 testing machine according to the Norm (Fig. 2).

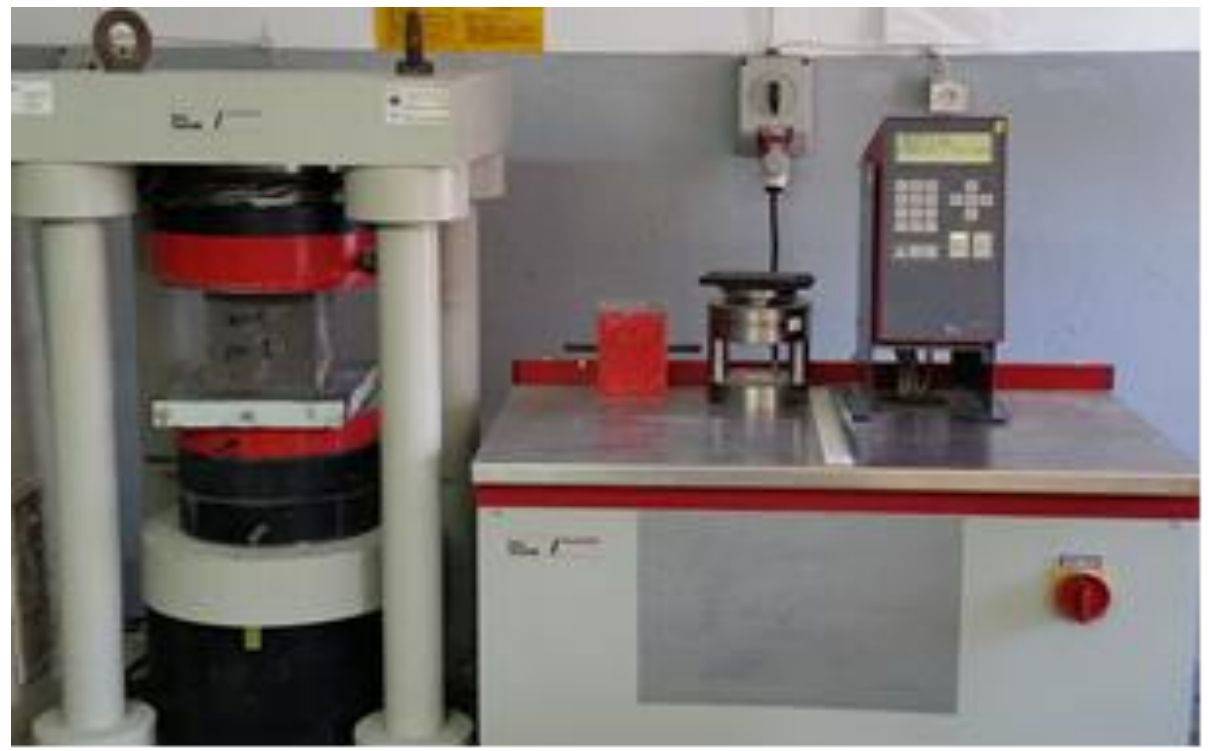

Figure 2. Testing machine „Toni Technik Zwick” (own elaboration)

Based on the methodology included in the PN-88 / B-06250 standard, the test of concrete absorbability of individual series and the frost resistance test were performed by the direct method for the F100 resistance class (Fig. 3). 

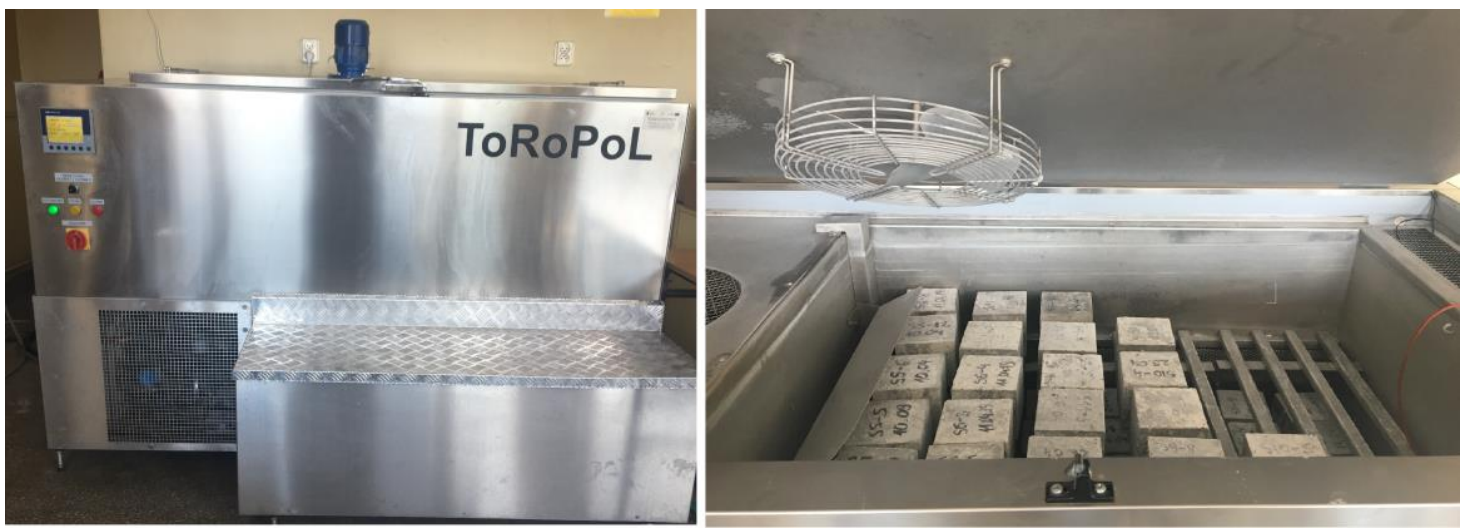

Figure 3. Device for testing frost resistance (own elaboration)

\section{Research results}

A test was carried out for the concrete mix: air content with the use of pressure method and consistency measured by the use of concrete slump test. Table 2 presents the properties of particular concrete mixtures.

Table 2. Research results of the concrete mixtures of particular series.

\begin{tabular}{|c|c|c|c|}
\hline $\begin{array}{c}\text { Concrete } \\
\text { series }\end{array}$ & $\begin{array}{c}\text { Consistency - } \\
\text { concrete slump test } \\
\text { [mm] }\end{array}$ & $\begin{array}{c}\text { Consistency class marked } \\
\text { by the concrete slump test } \\
\text { S }\end{array}$ & $\begin{array}{c}\text { Air } \\
\text { content } \\
\text { [\%] }\end{array}$ \\
\hline SK & 128 & S3 & 2.50 \\
\hline S1 & 135 & S3 & 2.35 \\
\hline S2 & 140 & S3 & 1.95 \\
\hline
\end{tabular}

Source (own elaboration)

At the experimental design stage of the concrete, the consistency S3 was assumed (precipitation of the cone within 100-150 mm), such consistency was obtained for the concrete mixture of the control series. Dosing for the next series of ground slag was found that the concrete mix became more fluid but the initial consistency of S3 did not change. The applied waste slightly improves the workability and consistency of the concrete mix.

No aeration agents were applied to the concrete mixes. The air content in the concrete mix of control series 1 was $2.5 \%$. The addition of ground slag to the concrete mix (S1 and S2) caused, in both cases, a decrease in the air content to $2.35 \%$ and $1.8 \%$ respectively.

The results of the experiment of durability of compressive strength are presented in Figure 4.

The average compressive strength of the control concrete series (SK) measured after 7 days equalled $\mathrm{f}_{\mathrm{cm}}=42.6 \mathrm{MPa}$. Adding slag, ground once, as a substitute of cement caused a decrease in average of compressive strength. After 7 days of maturing, the biggest decrease in compressive strength was examined in $\mathrm{S} 1$ series. The decrease of the $\mathrm{S} 2$ series in relation to the control concrete series equalled $19.1 \%$.

The average compressive strength of the control concrete series (SK), measured after 28 days equalled $\mathrm{f}_{\mathrm{cm}}=49.3 \mathrm{MPa}$. In both concrete series ( $\mathrm{S} 1$ and $\mathrm{S} 2$ ), to which wastes 
were added, the decrease in relation to the control concrete series equalled $45.7 \%$ and $22.7 \%$, respectively.

The average compressive strength of the control concrete series (SK), measured after 56 days of maturing equalled $\mathrm{f}_{\mathrm{cm}}=49.9 \mathrm{MPa}$. After 56 days of maturing, the decrease of the compressive strength for series S1 equalled $29.8 \%$ and for series S2 the compressive strength was on the similar level as in the control series (SK).

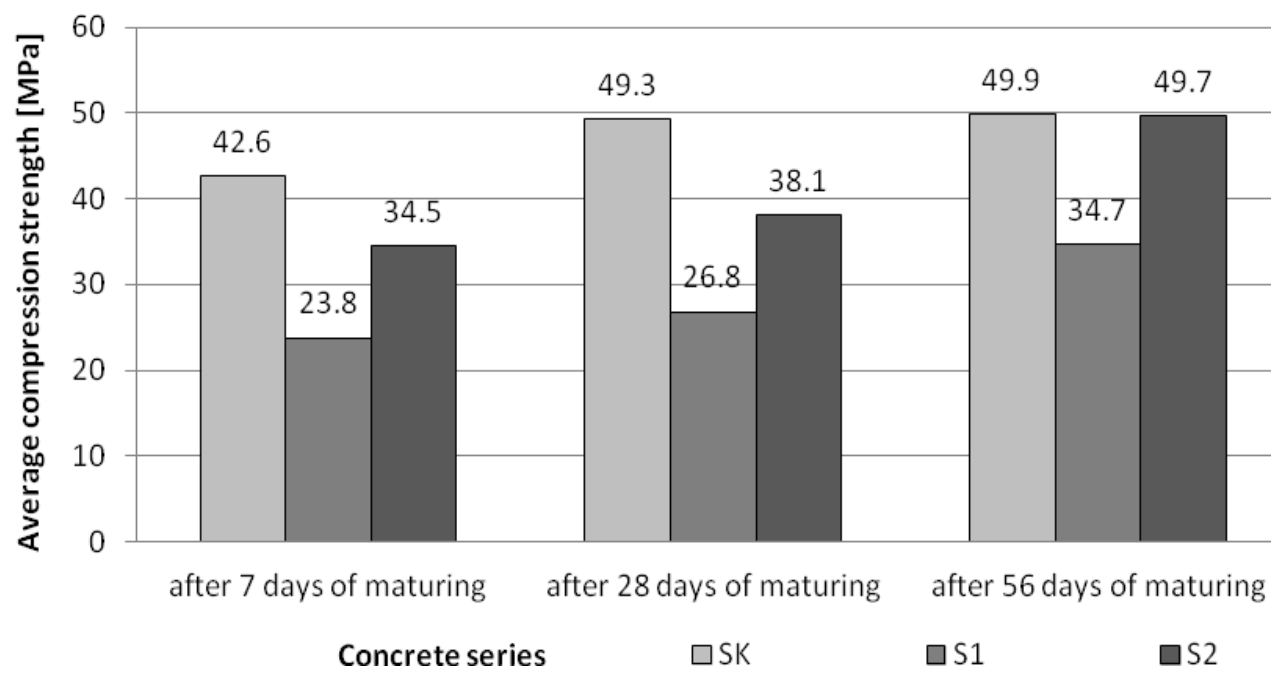

Figure 4. Average compressive strength of concrete of particular series (own elaboration)

On the basis of the methodology included in Norm PN-88/B-06250 B, an experiment of absorbability of particular series was conducted and the findings are presented in Table 3. According to the above-mentioned Norm, the absorbability of concrete exposed to environmental influences should not be bigger than $5 \%$. However, for concrete protected from direct weather conditions should not be bigger than $9 \%$. Both the control concrete and the concrete modified by means of volatile ashes reached the absorbability within $5.4-5.9 \%$.

Table 3. Results of frost resistance and absorptivity tests of cement for particular series

\begin{tabular}{|c|c|c|c|}
\hline \multirow{2}{*}{$\begin{array}{c}\text { Concrete } \\
\text { series }\end{array}$} & $\begin{array}{c}\text { Average mass } \\
\text { loss } \Delta G(\%)\end{array}$ & $\begin{array}{c}\text { Average } \\
\text { decrease of } \\
\text { compressive } \\
\text { strength } \Delta \boldsymbol{R}(\%)\end{array}$ & $\begin{array}{c}\text { Absorptivity } \\
(\%)\end{array}$ \\
\hline SK & 0.11 & 17.4 & 5.4 \\
\hline S1 & 0.06 & 18.3 & 5.8 \\
\hline S2 & 0.17 & 50.0 & 5.9 \\
\hline
\end{tabular}

Source (own elaboration)

The analytical determination is taken as positive if after carrying out of $n$ cycles of freezing and thawing, required by certain frost resistance class: the average decrease of compressive strength does not exceed $20 \%$, the average loss in mass does not 
exceed $5 \%$ and none of the examined samples breaks or scratches. The decrease of resistance for alternate freezing and thawing of the control series equalled $17.4 \%$. As presented in Table 2, the S1 and S2 concrete series modified by means of volatile ashes, gained from incineration of wastewater sludge, showed much smaller decrease of resistance for alternate freezing and thawing, and it equalled $18.3 \%$ and $50.0 \%$, respectively. The loss of mass for all concrete series was in the range of between $0.06 \%-0.17 \%$.

\section{CONCLUSIONS}

The results obtained in the present study show that it is impossible to use slag, gained from wastewater sludge incineration in fluidized-bed furnace in sewage treatment plants, in concrete technology. The use of slag, ground once in the disintegrator as a substitute of cement and aggregate with $\mathrm{P} / \mathrm{C}=0.165$ and $\mathrm{P} / \mathrm{C}=0.330$ ratios, causes a decrease of in compressive strength of concrete samples in relation to the control concrete series as well as bigger decrease in compressive strength after frost resistance test.

\section{REFERENCES}

Brózda, K., Selejdak, J., 2016. Analysis of FRP bars used as reinforcement in concrete structures, Production Enginering Archives 12(3), 2-4, DOI: 10.30657/pea.2016.12.01

Halbiniak, J., 2012. Projektowanie składu betonowego z dodatkiem popiołów lotnych oraz ich wpływa na tempo przyrostu wytrzymałości, Budownictwo o Zoptymalizowanym Potencjale Energetycznym 2 (10), 29-36.

Janecka, L., Siemiątkowski, G., 2012. Odpady denne z kotłów fluidalnych charakterystyka fizykochemiczna, ocena zagrożenia dla środowiska i możliwości zagospodarowania w produkcji klinkieru portlandzkiego, Prace Instytutu Ceramiki i Materiałów Budowlanych 5, 89-101.

Jura, J., Ulewicz, M., 2018. Application of fly ash and CRT glass waste In cement mortars. Stinetific Review - Engineering and Environmental Sciences 27, 348-354, DOI: 10.22630/PNIKS.2018.27.3.34

Jura, J., Ulewicz, M., 2017. Wpływ dodatku popiołu dennego ze spalania biomasy na wybrane właściwości zapraw cementowych. Materiały Budowlane 5, 77-78, DOI: 10.15199/33.2017.05.32

Kosior-Kazberuk, M., 2011. Nowe dodatki mineralne do betonu, Budownictwo i Inżynieria Środowiska 2, 47-55.

Pietrzak, A., Ulewicz, M., 2018. The effect of the addition of polypropylene fibres on improvement on concrete quality, QPI 2018, MATEC Web of Conferences 183, 02011, DOI: $10.1051 /$ matecconf/201818302011

Rutkowska, G., Fronczyk, J., Wichowski, P., 2018. Badanie możliwości wykorzystania popiołów lotnych z termicznego przekształcania osadów ściekowych do produkcji betonów zwykłych, Rocznik Ochrona Środowiska 20, 1113-1128.

Środa, K., Kijo-Kleczkowska,A., Otwinowski, H., 2012. Termiczne unieszkodliwianie osadów ściekowych, Inżynieria Ekologiczna 28, 67-81.

PN-EN 206:2014 Beton - Wymagania właściwości, produkcja i zgodność.

PN-88/B-06250 Beton zwykły. 